\title{
THE INFLUENCE OF FOREIGN LABOUR FORCE ON SERVICE PROVISION AND HOTEL GUESTS' EXPERIENCE - THE CASE OF COASTAL CROATIA
}

\author{
Danijela Ferjanić Hodak \\ Oliver Kesar \\ Ingeborg Matečić
}

https://doi.org/10.20867/tosee.05.52

\begin{abstract}
Purpose - The main purpose of this study is to analyse the influence of foreign labour force on hotel business in Coastal Croatia. Main objectives are to: 1) shed more light on foreign labour migration and related trends, 2) investigate attitudes regarding the participation of foreign labour force in hotel service provision, and 3) incorporate these trends and attitudes into discussion on authentic tourist experience.

Methodology - Two structured questionnaires were used to collect primary data: 1) aimed at examining the guests' attitudes regarding the impact of foreign migrant workers' cultural background on their experience and sense of place, and 2) aimed at hotel managers to identify to what extent labour migration affects the employment in hotels. For the evaluation of data, both inferential and descriptive statistics were used. Desk research method included the compilation of available findings on labour migration, sense of place and the impact of labour force cultural identities on guest experience.

Findings - This study revealed that the engagement of foreign labour force in hospitality industry has relatively strong impact on guest experience with a destination, as well as on hotel managers' decision making process regarding employment of domestic/foreign workforce.

Contribution - The systematization and analysis of literature on labour migration represents theoretical contribution of the paper, while the empirical contribution comes from the analyses of collected data related to employment of migrant workers. Practical contribution arises from the primary research which indicates current trends, attitudes and policies for managing labour migration in hospitality industry.
\end{abstract}

Keywords labour force, labour migration, hotel companies, Coastal Croatia

\section{INTRODUCTION}

The rapid growth of both tourism demand and supply at the global level in the recent decades, and the significant market failures in many countries that occurred as a consequence of the global economic crisis in 2008 have resulted with higher labour migration flows. These fluctuations go beyond regional and national boundaries to transnational or even transcontinental movement of people looking for better working conditions and higher wages. Such trends have been supported by many factors and processes, such as, globalization, demographic changes, market deregulation, mergers and acquisitions, downsizing, widespread availability of information (on immigration policies, vacancies and labour shortages), introduction of new technology, etc. 
ToSEE - Tourism in Southern and Eastern Europe, Vol. 5, pp. 275-289, 2019

D. Ferjanić Hodak, O. Kesar, I. Matečić: THE INFLUENCE OF FOREIGN LABOUR FORCE ON ...

In many countries, the tourism system, including the hospitality industry, is seen as a powerful mechanism for economic and social development of places and communities, providing various job opportunities primarily for domestic, but also for foreign labour force. While labour migration to, from and within the hospitality industry is by no means a new phenomenon, especially in countries dependent on economic benefits from tourism, it is essential to understand the nature, scope and effects of labour migration on host communities, local cultural identities, domestic workforce as well as guest experience with a service provider and/or tourism destination.

Since joining the European Union in July 2013, Croatia has lost more than 150,000 workers, which can be considered as huge economic, social and demographic losses. During the same period, many foreign workers found their jobs in Croatia, mostly in the tertiary sector that encompasses also workplaces in accommodation facilities, restaurants, bars, clubs etc. Besides the cross border labour migration, there is also an internal migration of workers who change their place of residence within Croatia on temporary (seasonal) or permanent basis. Therefore, the main purpose of this study is to analyse the influence of foreign labour force migration on employment and guest experience of large hotel companies in Coastal Croatia. In order to reach the research endpoints, in terms of better understanding of the relationship between employment issues and guest experiences related to the engagement of foreign workforce, two sets of attitudes were investigated and analysed. The first one examines the attitudes of hotel guests regarding the impact of foreign migrant workers' cultural background on their experience and the sense of place they visited. The second one focuses on attitudes expressed by managers of large hotels in the Coastal Croatia with the aim to identify to what extent labour migration affects the employment with regard to workers' country of origin and how it influence on the sense of place and local culture.

This paper is structured in three main sections. The first section provides a theoretical background on labour migration in general, labour migration in hospitality industry and the relationship of the guest experience and the sense of place. The second section briefly explains the methodology used in this research, while the third section discusses the research results and provides some managerial implications of this study.

\section{THEORETICAL BACKGROUND}

\subsection{The concept of labour migration}

The mass movement of people escaping from market failures in their home countries towards developed countries, commonly defined as economic migrations, became a global trend since the onset of the World economic crisis in 2008. Changes in demand, labour productivity, levels of investment in human labour, family circumstances and general economic conditions, have influenced the labour market, so part of workers decided to find new employer, occupation or job in another geographical area (McConnell and Brue, 1992, 439). This phenomenon, known as labour mobility influences not only the labour market, but the global economy to a large extent. In both economic theory (Baum, 2007; Choi et al., 2000; Janta et al., 2011a; Szivas et al., 2003; Vaugeois and Rollins, 2007) and practice there are two primary types of mobility: 1) 
ToSEE - Tourism in Southern and Eastern Europe, Vol. 5, pp. 275-289, 2019

D. Ferjanić Hodak, O. Kesar, I. Matečić: THE INFLUENCE OF FOREIGN LABOUR FORCE ON ...

occupational mobility - involves an employee's shift from her/his main occupation to another type of occupation or economic activity, usually within the same place of residence, and 2) geographic mobility - implies the change of a geographic area in which employee work, but usually remains within the same occupation or job type. This type of mobility represents the subject of this paper.

As one of the most intriguing social and economic challenges of the $21^{\text {st }}$ century, labour migration raises many discussions among governments, academics and international organizations due to its occurrence in literally every part of the world. The global access to information, particularly those of economic progress in developed countries, working permits and visa requirements, made a participation in labour migration easier than ever before. In spite of the fact that the remuneration is declared as the main reason for labour migration, the understanding of nature, causes and trends related to this phenomenon is quite complex. The importance of monitoring migration processes has led to the development of different theories, whose purpose is to explain the causes and trends of labour migration. The most important migration theories are, as Massey et al. $(1993,436)$ stated, neoclassical macroeconomic theory, neoclassical microeconomic theory, new economics of migration, dual labour market theory and world system theory. Aforementioned theories have identified several key macroeconomic factors of migration, which include: labour supply and demand, the level of wages, the level of urbanization, the number of people who have previously migrated, the rate of employment growth and the level of education. In addition to that, personal factors also play an important role in decision making process whether to migrate or stay. According to Navratil and Doyle $(1977,1548)$, these factors include: age, gender, degree of education, current working status, marital status, lifestyle and previous migration experiences. Therefore, data collection on migration is a complex task with many issues that have to be considered and resolved.

\subsection{Labour migration in tourism and hospitality industry}

The labour migration can be found in almost every economic activity, including a wide range of tourism related activities. The understanding of the relationships between the tourism employment and labour migration starts with clarifying the key facts, attributes and peculiarities of the tourism system primarily characterized by highly fragmented economic structure, spatial dispersion of business units, below average wages and seasonal variations in demand for workforce. Special attention should be given to four important facts regarding the labour migration either from, to or within the tourism system: 1) the rapid development of technology shifts human work from primary and secondary sectors towards the tertiary sector, especially tourism where substitution of human work with technological solutions is still low; 2) constant growth of tourism demand and consumption leads to a continuous increase in demand for labour force in many tourism-related activities, which additionally support labour migration towards tourism destinations and sites; 3 ) tourism workforce is dominated by less educated, less skilled and seasonally oriented workers, which enables individuals from various socially vulnerable groups (i.e. women, youth, migrants, aging workers etc.) to find their jobs in tourism, which are usually outside of their place of residence and require knowledge and skills that need to be adopted through special education and training; and 4) seasonality of both tourism demand and supply undoubtedly affects the patterns of tourism 
ToSEE - Tourism in Southern and Eastern Europe, Vol. 5, pp. 275-289, 2019

D. Ferjanić Hodak, O. Kesar, I. Matečić: THE INFLUENCE OF FOREIGN LABOUR FORCE ON ...

employment throughout the year, so increasing number of vacancies during the high tourism season encourage temporary labour migration (Ferjanić Hodak, 2017, 82-84). According to Baum $(1993,48)$, labour mobility in tourism is also supported by large number (and a diversity) of business units that tourism system consists of, the ability to transfer skills from one organization to another, rigidity of jobs within the organization, jobs at higher positions require the breadth of knowledge (although not depth), flexible working hours, etc.

In spite of significant alterations in migration patterns across regions, the geographical positions of an employee and an employer have common characteristics. Labour migrants from less developed countries usually work on less paid jobs that do not require special skills. These workers accept the job because the income it generates is usually far above the average income they could earn in their home country. The residents in tourism destinations often refuse to work on less paid jobs, not just because of the money, but also because of the status (image) it provides. On the other hand, labour migrants from developed countries often work as expatriate managers in large companies. In his analysis on labour migration in hotel industry, Joppe (2012, 664-667) came to the following cognitions: 1) high rates of emigration and immigration have been recorded in Greece, Italy, Portugal and Spain due to the lack of linguistic barriers, which is not the case in Finland, Japan and Korea, where low rates of emigration and immigration have been recorded; 2) the rise in the number of immigrants in Greece, Portugal, Italy and Spain is the result of a more intensive tourism development and a the growth of tourism demand in these countries; and 3) high migration rates are specific for developing countries, while developed countries have high rates of immigration, at the same time low rates of emigration. On account of these findings, if migrant-emigrating country faces increasing number of tourists, there is a need for a new workforce which is frequently not met by the local labour supply, which directly affects migrant inflows. It is therefore obvious that labour mobility in tourism is influenced by different factors and it is not easy to predict.

One of the peculiarities of international labour migration in tourism is the language barrier. As noted by Janta et al. (2012, 431), most labour migrants can work in tourism despite the lack of language skills, but only on those jobs that do not require direct contact with tourists. These jobs are mostly less paid, of poor performance, and poor prospects for promotion. Labour migrant who decide to stay in another country for a longer period of time usually learn local language and therefore create the opportunity to be promoted to a better job. However, the knowledge of local language does not guarantee a better job position, due to the fact that they are not native speakers.

All previously mentioned factors make tourism attractive for workers who see this type of engagement as a kind of "port in a storm", which results in a large number of migrant workers. One of the key economic activities within the tourism system, highly affected by both occupational and geographical labour migrations, is the hospitality industry in which demand for workforce depends on many economic, social and natural parameters. Previous studies in this field have revealed that the "high turnover rates and specific working hours in hospitality industry increase labour force demand" (Janta et al., 2011b, 1007). Szivas $(1997,73)$ argued that the main advantage of the hospitality industry, when 
ToSEE - Tourism in Southern and Eastern Europe, Vol. 5, pp. 275-289, 2019

D. Ferjanić Hodak, O. Kesar, I. Matečić: THE INFLUENCE OF FOREIGN LABOUR FORCE ON ...

it comes to attracting the labour force, is the fact that it embraces a large number of occupations, skills, different working conditions and earning possibilities.

According to Baum $(2012,1)$, there are 11 globally applicable conclusions related to labour migration in hospitality industry: 1) labour force involved in migration is very important for hospitality industry; 2) the experience of workers involved in migration in hospitality industry largely depends on the country, culture and occupation they come from; 3) the income of migrants contributes financially to many countries; 4) workers from poor countries are doing more difficult and less paid jobs, while workers from developed countries mostly take managerial positions; 5) workers participating in labour migration have certain skills that can improve organizational culture; 6) large hotel companies encourage and protect migrant workers; 7) small hotel businesses are more concerned with migrant workers adaptation to work and the new environment; 8) migrants in some developed countries are often overqualified for the job they perform; 9) migrant workers are often limited in their progress; 10) migrant workers stay in hospitality industry for the short period of time; and 11) employers often do not want to invest in the education of employees participating in mobility.

\section{3. 'Space and place' as a framework of cultural identity in tourism}

There are three important issues regarding the migrant employees' cultural background and their engagement in tourism service providing: 1) how the familiarity with the local culture and the knowledge of local language can influence the quality of services provided; 2) does the knowledge of local language and local culture demonstrated by workforce in direct contact with tourists provide authentic experience; and 3) does only local labour force reflects cultural identity and a sense of place (tourism destination).

In order to clarify the relations between cultural identities, sense of place and tourism destinations it is important to search for theoretical implications outside of economic studies. The space in the social and human sciences is thought outside the physical frames and is understood by the expression of society (De Certeau, 1984; Giddens, 1991; Harvey, 1992). Space and place are terms that are often researched in the scientific work of anthropologists and ethnologists, as well as many other scholars of various disciplines of social and human sciences such as architecture, archaeology, philosophy, cultural geography, urbanism etc. Although the research topics on space and place originate from humanistic geography (Tuan 1977; Relph, 1976; Baskar, 2011), the centre of anthropological occupations has always represented the spatial dimension of the beliefs and practices of different cultures and cultural identities. In anthropology, since the 1990 s, an increasing interest in space and space issues has begun to emerge (Soja, 1989) and the spatial dimensions of culture come to the fore, leaving the concepts of space in the background of ethnographic past. Realizing that space is one of the major components of socio-cultural theories, anthropologists have begun to deal with rethinking and reconsidering the perception of culture in relation to space (Low and Lawrence-Zuniga, 2003). The last decade of the 20th century marked the so-called "spatial turn", characterized by a new way of thinking about space. The traditional understanding of space, place and culture, their "isomorphism" (Gupta and Ferguson, $1997,34)$ begins to be critically questioned in the conditions of the modern age, the phenomena of globalization and migration, and indeed the postcolonial state of the world 
ToSEE - Tourism in Southern and Eastern Europe, Vol. 5, pp. 275-289, 2019

D. Ferjanić Hodak, O. Kesar, I. Matečić: THE INFLUENCE OF FOREIGN LABOUR FORCE ON ...

and late capitalism. The anthropological concept of space and place is examined from notions of local space, perceiving local as the creator of social practice and socio-cultural spaces, to a "global sense of place" (Massey, 1994).

However, tourist places are observed as contested and transnational spaces (Low and Lawrence-Zuniga, 2003). A tourist place is a contested in terms of the encounters and the influence of various social, political and economic interests. As Low and LawrenceZuniga pointed out, the biggest threat to local cultures is the great commercial success of mass tourism that is increasingly organized through international cooperation networks (Greenwood, 1989, Boissevain 1996, Low and Lawrence-Zuniga, 2003). On the other hand, some tourist sites serve the purpose of creating a national identity and play an important role in the ideological conception of the rule of the state (Selwin, 1996, Low and Lawrence-Zuniga, 2003). Scientists agreed that space is commonly described as a key dimension in shaping social identities, whether national or regional, and identities are understood as something which is created in connection with specific place, both territorial and social (Martin, 2008). Largely, the topic of the sense of place researches the experience dimension of how places are known, imagined and reflected as well as bonded to identities and explores cultural practices by which places gain meaning and can be actively felt (Feld and Basso, 1996). Considering the place in terms of tourism destination Cooper and Hall (2008) argued that sense of place refers to the subjective, individual and sentimental attachments and relationships tourists have to a place (Cooper and Hall, 2008). The sense of place of those tourists already present in a destination develops from the experience of the landscape and the local people (Cooper and Hall, 2008). If local community shapes the sense of place then it could be argued that local workforce in the direct contact with tourists create and reflect specific cultural identity of the place and shape the sense of place (destination). On the other hand, the foreign workforce does not necessarily represent the threat to authenticity, but could produce different experiential depths as regards the overall guest experience of a tourism destination.

\section{METHODOLOGY}

This paper is focused on exploring foreign labour force in the hospitality industry, using general public as customers and large hotel companies in the coastal part of Croatia as service providers, who both agreed to participate in this research. Foreign labour force includes all employees who came to Croatia from some other country. To achieve the goal, the desk research and survey were used as methods of collecting data. The main sources for the desk research were previously published contributions related to labour migration/mobility, tourism employment, cultural identities, and the concept of space and place, in order to create a theoretical background. For the purpose of better understanding the relationship between employment issues and guest experiences regarding the engagement of foreign workforce in hotel business, two sets of attitudes were investigated and analysed using data collected from October, 2018 until January, 2019. Two separate questionnaires were distributed by digital social networks and direct e-mailing system. Both questionnaires were self-completing and highly structured. The first one, aimed at questioning attitudes and opinions of tourism demand regarding foreign migrant workers and the effects on creating authentic guest experience, was 
ToSEE - Tourism in Southern and Eastern Europe, Vol. 5, pp. 275-289, 2019

D. Ferjanić Hodak, O. Kesar, I. Matečić: THE INFLUENCE OF FOREIGN LABOUR FORCE ON ...

completed by 311 respondents. The second one was sent to the human resource management departments of the largest hotel companies in Coastal Croatia, who have distributed the questionnaire to general managers of company's hotels. The main aim was to identify how and to what extent labour migration affect the companies in the context of tourism destination they operate. In total, 56 hotel managers were completed the questionnaire. The descriptive statistics were used for primary data analysis and the inferential statistics were used in answering the research questions.

\section{RESEARCH RESULTS AND DISCUSSION}

\subsection{Statistical background}

The structure of tourist accommodation facilities in Croatia is generally considered unsatisfactory across tourism experts, and is mainly shaped by the characteristics of key tourism generating markets, seasonal patterns of tourism related activities, ownership of the real estate, weak country image on international market and the legacy of passive tourism planning during the past 50 years. According to Croatia's Ministry of tourism (2019), in August 2018, the total tourism accommodation capacity was 1.27 million beds, predominantly in Holiday and other short-stay accommodation with significant share of $63.1 \%$ of total, Camping sites/grounds with $18.6 \%$, Hotels and aparthotels with $10.3 \%$, and $8 \%$ in other types of accommodation available to tourists. The same data source keeps record on total of 128,500 hotel beds in 731 hotel premises of which $5.6 \%$ were $5^{*}$ hotels, $43 \%$ were $4^{*}$ hotels, $43.8 \%$ were $3^{*}$ hotels, and $7.6 \%$ were $2 *$ hotels. The majority of hotel bed capacities were in $4 *(48.1 \%)$ and $3 *$ hotels $(34.8 \%)$. Almost $90 \%$ of all hotel beds are situated in the Coastal Croatia. In 2018, all hotel companies in Croatia have accounted for nearly 20 million overnight stays ( $22 \%$ of total) with annual occupancy rate of $42.2 \%$ (154 nights per year).

Based on research provided by Čižmar (Korda, 2017), international hotel brands that operate in Croatia hold a cumulative share of about $25 \%$ of Croatia's total hotel accommodation capacity. Hotel market in Croatia is characterized by a very high level of consolidation, as it is evidenced by the fact that the 10 largest domestic hotel companies are managing more than $40 \%$ of the total hotel rooms. Considering national hotel brands, largest shares of the hotel market in Croatia is held by three leading hotel groups: 1) Valamar Riviera (nearly 208 million euros in revenue; 2,600 permanent and 4,800 seasonal employees), 2) Lukšić Group (with total of 197 million euros in revenue and 2,770 permanent employees), and 3) Maistra (153 million euros in revenue; 1,560 permanent and 2,930 seasonal employees). Some of these companies were participated in survey for this study. The rest of $35 \%$ of the hotel market in Croatia is held by small and medium size hotel companies.

The emergence of the global economic crises in 2008 has triggered the fundamental changes in the way international tourism labour market continued to operate ever since. During the past 10 years, the crisis had a profound impact on Croatia's tourism, causing a variety of demographic, social and economic consequences and challenges. A sudden decrease in consumption, production and service delivery has generated a huge drop in employment and increased unemployment. These negative trends have been intensified 
ToSEE - Tourism in Southern and Eastern Europe, Vol. 5, pp. 275-289, 2019

D. Ferjanić Hodak, O. Kesar, I. Matečić: THE INFLUENCE OF FOREIGN LABOUR FORCE ON ...

in 2013, when Croatia became a full member state of the European Union. The internal tourism labour market started to show different patterns of full-time, part-time and seasonal employment, because a significant number of Croatian citizens emigrated from the country. Since then, as Babić and Račić $(2018,4)$ claim, the loss of human capital is high and increasing over time. Employers (particularly in tourism) acknowledge labour shortages, but reacted to them by asking the government to increase the quotas for foreign workers. The increasing number of issued work permits for foreign labour force during the past eight years is shown in Table 1.

Table 1: Work permits issued for foreign workers in Croatia, 2012-2019

\begin{tabular}{|c|c|c|c|}
\hline Year & $\begin{array}{c}\text { Total work permits } \\
\text { issued }\end{array}$ & $\begin{array}{c}\text { Work permits issued for } \\
\text { tourism and hospitality } \\
\text { industry }\end{array}$ & Share \\
\hline 2012 & 3,988 & 145 & $3.6 \%$ \\
\hline 2013 & 2,329 & 105 & $4.5 \%$ \\
\hline 2014 & 2,256 & 100 & $4.4 \%$ \\
\hline 2015 & 1,730 & 106 & $6.1 \%$ \\
\hline 2016 & 3,115 & 85 & $2.7 \%$ \\
\hline 2017 & 9,079 & 175 & $1.9 \%$ \\
\hline 2018 & 38,769 & 7,930 & $2.0 \%$ \\
\hline 2019 & 65,100 & 10,611 & $16.3 \%$ \\
\hline
\end{tabular}

Source: Republic of Croatia, Official Gazette (2012-2019)

Data in Table 1 show that, since 2017, the number of work permits is dramatically increasing, particularly when it comes to the employment of foreign workers in tourism and hospitality industry. Beside the increase of labour force coming from abroad, according to Knežević et al. (2018), currently growing problem in Croatia is the continuous increase in number of Croatian citizens who leave their home country in order to settle in one of the EU member state. The Croatia's official statistical database keeps record of nearly 150,000 people who emigrated from Croatia between 2013 and 2017 to live and work in other countries (CBS, 2018), which can be regarded as a great loss of labour force, but also of demographic potential. Since there is no evidence of different trends, it can be expected that in the upcoming years the demographic structure of labour force in Croatia will continue to irreversibly change.

The outflow of domestic labour and the increase in number of workers coming from abroad cause alterations in workforce supply and demand, challenging governments and employers in tourism to prepare foreign workers on domestic work conditions. The integration of labour coming from different countries into new setting has both positive and negative effects, depending on the company's target markets, place it operates and the visitors' expectations. The results of the primary research concerning tourists' attitudes and opinions on creating authentic guest experience related to presence of foreign labour force, have raised various issues. However, the situation is changing and tourists, as well as employers, started to adapt to such increasing trend. 
ToSEE - Tourism in Southern and Eastern Europe, Vol. 5, pp. 275-289, 2019

D. Ferjanić Hodak, O. Kesar, I. Matečić: THE INFLUENCE OF FOREIGN LABOUR FORCE ON ...

\subsection{Attitudes of tourism demand regarding labour migration, cultural identity and sense of place}

The questionnaire aimed at exploring tourism demand's attitudes regarding labour migration consisted of 12 questions, of which 11 were focused on socio-economic status and travel habits, while the last question set was dedicated to measure the level of agreement with the presence of foreign workers. The educational structure of sample reveals that $56.3 \%$ of a total of 311 respondents have a bachelor degree, followed by $28.9 \%$ of them with a master or doctoral degree, while $14.8 \%$ were respondents who have completed a high school. Roughly half of the respondents $(50.8 \%)$ travel for tourism purposes more than three times per year, 33.4\% of included respondents travel two times per year, $13.8 \%$ travels on average once per year, while $1.9 \%$ travels less than once per year. Majority of respondents stays in a tourism destination between 4-6 days (51.8\%), $24.8 \%$ stays 7-13 days and $20.6 \%$ stays 2-3 days. Regarding the travel companions, $34.4 \%$ of respondents travel with family, $24.8 \%$ with friends, $20.6 \%$ with partner, $11.9 \%$ with colleagues and $8.4 \%$ travel alone. The most frequent motivation is travelling for holiday purposes, which accounts for $63 \%$, followed by business related activities with $22.2 \%$ and recreation activities with $4.8 \%$. Less than half of the respondents $(49.5 \%)$ frequently stay in hotels and similar premises, $44,4 \%$ of them pays for a short term rental accommodation, while 2,6\% of respondents uses some other form of accommodation facilities. The income distribution within the sample revealed that $33.4 \%$ respondents earn more than 1,300 euros, $36.6 \%$ earns between 850 and 1,300 euros; $19.9 \%$ between 450 and 850 euros; $10.3 \%$ earns less than 450 euros. On question regarding the average daily expenditure while traveling, respondents have reported an overall average of 120 euros per day, which is about 40 EUR higher than the average daily expenditure reported in TOMAS (Institute for Tourism, 2018) research for summer visitors in tourism destinations along the Coastal Croatia in 2017.

The key set of questions sent to a sample of tourism demand referred to how the knowledge of local language and local culture demonstrated by domestic vs. foreign employees affect the perception of the quality of hotel service, as well as how employees influence the authenticity of guest experience, the sense of place and cultural identity of tourism destination (Table 2). Respondents have rated statements from 1 (if completely disagree) to 5 (if completely agree) on five-point Likert scale.

The data shown in Table 2 revealed that none of the statements was fully supported or strongly objected by the surveyed participants. The respondents rated higher hotel employees' affiliation with the local community and local cultural setting while rating the quality of hotel services provided, and in the process of creating authentic experience of a tourism destination. The lowest rated statement "Foreign labour force diminishes overall experience of the destination for tourists" did not appear to be important to this group of respondents $(\mathrm{M}=2.78)$.

Another goal was to examine if there is a significant relationship between the attitudes of respondents related to domestic and foreign labour depending on the characteristics of the respondents. Examined characteristics are related to the age, gender, degree of education, frequency and duration of travel, travel companions, motivation and income. 
ToSEE - Tourism in Southern and Eastern Europe, Vol. 5, pp. 275-289, 2019

D. Ferjanić Hodak, O. Kesar, I. Matečić: THE INFLUENCE OF FOREIGN LABOUR FORCE ON ...

Table 2: Impact of labour force cultural background on hotel guests' experience and sense of place $(n=311)$

\begin{tabular}{|l|c|c|}
\hline \multicolumn{1}{|c|}{ Statements } & Average & Mode \\
\hline $\begin{array}{l}\text { 2. Hotel employees in direct contact with guests have to be familiar } \\
\text { with local culture to provide quality hotel service. }\end{array}$ & 3.67 & 4 \\
\hline $\begin{array}{l}\text { 4. Hotel employees in direct contact with guests have to be familiar } \\
\text { with local culture to provide authentic experience. }\end{array}$ & 3.59 & 4 \\
\hline $\begin{array}{l}\text { 1. Hotel employees in direct contact with guests have to be fluent in } \\
\text { local language to provide quality hotel service. }\end{array}$ & 3.54 & 5 \\
\hline $\begin{array}{l}\text { 7. Local labour force in hotels reflects cultural identity of the } \\
\text { destination. }\end{array}$ & 3.34 & 4 \\
\hline $\begin{array}{l}\text { 3. Hotel employees in direct contact with guests have to be fluent in } \\
\text { local language to provide authentic experience. }\end{array}$ & 3.29 & 4 \\
\hline $\begin{array}{l}\text { 6. Contact between tourists and local labour force provides the sense } \\
\text { of place. }\end{array}$ & 3.28 & 4 \\
\hline $\begin{array}{l}\text { 5. Foreign labour force diminishes overall experience of the } \\
\text { destination for tourists. }\end{array}$ & 2.78 & 3 \\
\hline
\end{tabular}

Source: primary research

In order to determine the existence of the difference, the averages for each statement was calculated and coded. Respondents who consider that domestic labour force have a positive influence on the tourist's satisfaction was assigned number one, while the other respondents were assigned number two. Respondents who share the same average in both factors were encoded by zero and considered indifferent. In order to test the hypothesis, the $\chi^{2}$ independence test was used. The empirical $p$-value of the $\chi^{2}$ independence test for each individual variable is shown in Table 3.

Table 3: Pearson Chi-Square test results of respondents' attitudes related to domestic and foreign labour depending on respondents' characteristics

\begin{tabular}{|l|c|}
\hline \multicolumn{1}{|c|}{ Variable } & Asymp. Sig. (2-sided) \\
\hline Age & .996 \\
\hline Level of education & .296 \\
\hline Knowledge of foreign languages & .368 \\
\hline Travel frequency & .332 \\
\hline Duration of travel & .546 \\
\hline Travel companions & .030 \\
\hline Travel motivation & .700 \\
\hline Income & .750 \\
\hline
\end{tabular}

Source: primary research

The empirical p-value obtained by using the statistical tool for the seven (out of eight) observed characteristics is higher than the theoretical level of significance $\alpha$, while only "Travel companions" variable has low empirical p-value (.030). Therefore, it can be concluded that there is a significant relationship between the attitudes of respondents related to domestic and foreign labour depending on the respondent travel companions, while for all other examined variables there is no statistically significant relationship. 
ToSEE - Tourism in Southern and Eastern Europe, Vol. 5, pp. 275-289, 2019

D. Ferjanić Hodak, O. Kesar, I. Matečić: THE INFLUENCE OF FOREIGN LABOUR FORCE ON ...

Since business tourists are not concerned about whether they are served by domestic or foreign workers, business oriented hotels may employ mostly foreign employees, while hotels specialized for family vacations should predominantly employ domestic workforce. However, due to the absence of statistically significant relationship in all other observed variables, and the fact that conducted research is still a pilot one; it is not possible to make generally applicable conclusions.

\subsection{Attitudes of hotel managers regarding labour migration, guest experience and sense of place}

Second questionnaire was distributed to the hotel managers of the largest hotel companies that operate in the Coastal Croatia. According to the results, more than $60 \%$ of the hotels included in the research have foreign employees, but their share in total number of employees is only $5.7 \%$. The aim was to identify the current situation with employment of foreign workers, as well as the attitudes of hotel management concerning the engagement of the foreign labour in their premises. For that purpose, 10 statements related to the employment of foreign labour was created (Table 4).

Table 4: Influence of labour force origin on employment in hospitality industry $(\mathbf{n}=56)$

\begin{tabular}{|l|c|c|}
\hline \multicolumn{1}{|c|}{ Statements } & Average & Mode \\
\hline $\begin{array}{l}\text { 1. Domestic labour force (from the entire country) has the priority in } \\
\text { the employment process. }\end{array}$ & 4.45 & 5 \\
\hline $\begin{array}{l}\text { 2. Domestic labour force (from the same county of work place) has the } \\
\text { priority in the employment process. }\end{array}$ & 4.43 & 5 \\
\hline $\begin{array}{l}\text { 4. The employment process for foreign labour force is more } \\
\text { complicated and more expensive that domestic labour force } \\
\text { employment process. }\end{array}$ & 4.18 & 5 \\
\hline 9. Domestic labour force accepts foreign employees. & 3.63 & 4 \\
\hline $\begin{array}{l}\text { 10. The experience of employing foreign labour force can be evaluated } \\
\text { as positive. }\end{array}$ & 3.50 & 3 \\
\hline $\begin{array}{l}\text { 5. One of the employment barriers is the ignorance of local language } \\
\text { and local culture. }\end{array}$ & 3.34 \\
\hline $\begin{array}{l}\text { 7. Foreign labour force has positive effect on organisational culture of } \\
\text { the company. }\end{array}$ & 3.09 & 3 \\
\hline 8. Foreign employees are more motivated than the domestic ones. & 2.91 & 3 \\
\hline $\begin{array}{l}\text { 6. Foreign labour force is most often on jobs which do not include } \\
\text { direct contact with guests. }\end{array}$ & 2.61 \\
\hline $\begin{array}{l}\text { 3. Foreign labour force has lower labour productivity than the domestic } \\
\text { labour force. }\end{array}$ & 2.38 & 3 \\
\hline
\end{tabular}

Source: primary research

According to data shown in Table 4, six out of ten statements were in favour with employment of domestic workforce, while four statements are related with the benefits of employing foreigners. The research results showed that hotel managers prefer to engage domestic workers, but agree that employment of foreigners brings certain benefits. The average rating for statements related to the benefits of employing domestic employees is 3.59 , while the statements suggesting the benefits of foreign employees are 
ToSEE - Tourism in Southern and Eastern Europe, Vol. 5, pp. 275-289, 2019

D. Ferjanić Hodak, O. Kesar, I. Matečić: THE INFLUENCE OF FOREIGN LABOUR FORCE ON ...

rated with average of 3.49. The lowest rated statement was related to hotel managers' attitudes regarding labour productivity between domestic and foreign labour, which appeared to be practically equal in both segments of employees $(\mathrm{M}=2.38)$.

Therefore, it is possible to conclude that there is a certain difference between two groups of statements, but it is rather small, which means that hotel companies in the Coastal Croatia are open to employment of foreigners.

In the next step the research was aimed to examine whether there is a significant relationship between the size (small, medium or large) and the category of hotel (rated by stars), with attitudes toward engagement of foreign employees. For this purpose, the $\chi^{2}$ independence test was performed.

The empirical value of both tested variables is higher than the theoretical level of significance $\alpha(05)$. The empirical $p$-value for the hotel size variable is .554 , while the empirical p-value for the hotel category variable is 0.238 . Based on the results obtained it is possible to conclude that there is no statistically significant difference in the attitudes of the hotel according to the employment of foreigners depending on the size and category of the hotel.

\section{CONCLUSION}

Although labour migration has been a consistent theme in literature on sociology, anthropology and economy for a long time, constant changes in trends that shape the scope and intensity of migration still arise many questions and concerns. In general, labour mobility is generated by two main causes - the market failure in migrants' home regions/countries, and the increasing demand for labour in developed regions/countries with attractive and favourable working conditions for immigrant workers.

Many global factors determine employment and labour migration in tourism as well as in hospitality industry. Much of the focus is on the global size of labour market and spatial dispersion of work places, the prevalence of low educated and low skilled labour, constant growth of tourism demand and tourism supply, seasonal patterns of employment, high labour turnover rates, etc. Therefore, labour migration in tourism and hospitality industry is inevitable and ongoing phenomenon with all its positive and negative effects that needs to be carefully monitored and analysed.

When it comes to Croatia, desk research revealed the rapid growth of foreign employees in the hospitality industry, approved by government's decision to allow higher quotas for employment of foreign workers. In the survey conducted among tourism demand, hotel employees' affiliation with the local community and local cultural setting was rated important for the quality of hotel services and for authentic experience of a tourism destination. However, respondents did not find foreign labour force as limitation for guest overall experience of the destination. The second survey, conducted among hotel managers in companies located in Coastal Croatia, revealed that hotel managers prefer engagement of domestic labour force regarding the simplicity and lower costs of the employment process. It has also revealed that hotel managers have lower confidence to 
ToSEE - Tourism in Southern and Eastern Europe, Vol. 5, pp. 275-289, 2019

D. Ferjanić Hodak, O. Kesar, I. Matečić: THE INFLUENCE OF FOREIGN LABOUR FORCE ON ...

the foreign workers regarding their motivation and productivity. Therefore, the main challenge for human resource managers in tourism and hospitality industry, regarding the employment of migrant workers, is to better understand the factors that influence guest satisfaction with quality of provided hotel service, the sense of place and overall experience of a tourism destination.

The main limitations of this research lie in several following facts: 1) the analysis of collected primary data is static and does not provide insight into dynamic changes, 2) the surveys were conducted during the winter time when tourism-related activities were low, and 3) the sample of both groups of respondents can be considered relatively narrow. Therefore, the research findings in this paper cannot be regarded as generally conclusive, but indicative and useful for employment decision making processes.

\section{REFERENCES}

Babić, Z, and Račić, D. (2018), Labour Market Policy Thematic Review 2018: An in-depth analysis of the emigration of skilled labour - Croatia, European Centre of Expertise in the field of labour law, employment and labour market policy, Brussels.

Baskar, B. (2011), "Place, non-place: interdisciplinary deliberation of space and culture" (in Croatian), book review, Studia Ethnologica Croatica, Vol. 23, No. 1, pp. 365-368.

Baum, T. (2012), Migrant workers in the international hotel industry, International Labour Office, Geneva.

Baum, T. (Ed.) (1993), Human Resource Issues in International Tourism, Butterworth-Heinemann, Oxford.

Baum. T. (2007), "Human resources in tourism: Still waiting for change", Tourism Management, Vol. 28, No. 6, pp. 1383-1399. https://doi.org/10.1016/j.tourman.2007.04.005

Black, A. (1996), "Negotiating the tourist gaze: the example of Malta", in Boissevain, J. (Ed.) Coping with Tourists: European Reactions to Mass Tourism, Berghahn Books, Oxford, pp. 112-142.

Boissevain, J. (1996), "Introduction", in Boissevain J. (Ed.), Coping with Tourists. European Reactions to Mass Tourism, Berghahn Books, Providence, Oxford, pp. 1-26.

CBS (2018), Statistical Yearbook 2018, Croatian Bureau of Statistics, Zagreb.

Choi, J.G., Woods, R.H. and Murrmann, S.K. (2000), "International labor markets and the migration of labor forces as an alternative solution for labor shortages in the hospitality industry", International Journal of Contemporary Hospitality Management, Vol. 12, No. 1, pp. 61-67. https://doi.org/10.1108/09596110010305154

Cooper, C. and Hall, C.M. (2008), Contemporary tourism: an international approach, Elsevier, Oxford, Burlington.

De Certeau, M. (1984), The Practice of Everyday Life, University of California Press, Los Angeles \& London.

Feld, S. and Basso, K.H. (Eds.) (1996), Senses of place, Santa Fe, School of American Research Press, New Mexico.

Ferjanić Hodak (2017), "Impact of labour mobility on selected business Performance indicators in hospitality industry in Croatia", Acta Turistica, Vol. 29, No. 1, pp. 75-102. htpps://doi.org/10.22598/at/2017.29.1.75

Giddens, A. (1991), Modernity and Self-Identity: Self and Society in the late Modern Age, Polity Press, Cambridge.

Greenwood, D. (1989), "Culture by the pound: an anthropological perspective on tourism as cultural commoditization", in Smith, V.L. (Ed.) Hosts and Guests, Blackwell, Oxford, pp. 129-138.

Gupta, A. and Ferguson, J. (1997), Anthropological Locations Boundaries and Grounds of a Field Science, University of California Press, Berkeley, Los Angeles, London.

Harvey, D. (1992), The Condition of Postmodernity: An Enquiry into the Origins of Cultural Change, WileyBlackwell, Cambridge.

Institute for Tourism (2018), TOMAS Summer 2017 - Attitudes and Expenditures of Tourists in Croatia, Institute for Tourism, Zagreb.

Janta, H., Brown, L., Lugosi, P., and Ladkin, A. (2011a), "Migrant relationship and tourism employment", Annals of Tourism Research, Vol. 38, No. 4, pp. 1322-1343. https://doi.org/10.1016/j.annals.2011.03.004 
ToSEE - Tourism in Southern and Eastern Europe, Vol. 5, pp. 275-289, 2019

D. Ferjanić Hodak, O. Kesar, I. Matečić: THE INFLUENCE OF FOREIGN LABOUR FORCE ON ...

Janta, H., Ladkin, A., Brown, L., and Lugosi, P. (2011b), "Employment experiences of Polish migrant workers in the UK hospitality sector", Tourism Management, Vol. 32, No. 5, pp. 1006-1019. https://doi.org/10.1016/j.tourman.2010.08.013

Janta, H., Lugosi, P., Brown, L. and Ladkin, A. (2012), "Migrant networks, language learning and tourism employment", Tourism Management. Vol. 33, No. 2, pp. 431-439. https://doi.org/10.1016/j.tourman.2011.05.004

Joppe, M. (2012), "Migrant workers: Challenges and opportunities in addressing tourism labour shortages", Tourism Management, Vol. 33, No. 3, pp. 662-671. https://doi.org/10.1016/j.tourman.2011.07.009

Knežević, S., Kulaš Mirosavljević, A. and Duspara, L. (2018), "Mass migration - the fastest growing challenge of the European Union with special reference to Croatia", in Conference Proceedings of $4^{\text {th }}$ International Scientific Conference: Knowledge Based Sustainable Economic Development, Sofia, June $06^{\text {th }}$, pp. 665-672.

Korda, Z. (2017), Turističke brojke nadmašuju rekorde: Pogledajte tko bere vrhnje na Jadranskoj obali (Tourist figures outnumber the record: Look at cream skimming on the Adriatic coast), viewed 10 May 2019, https://www.tportal.hr/biznis/clanak/turisticke-brojke-nadmasuju-rekorde-pogledajte-tko-berevrhnje-na-jadranskoj-obali-20170801

Low, S. and Lawrence-Zúñiga, D. (Eds.) (2003), The anthropology of space and place, Blackwell, Malden, MA.

Martin, J. (2008), "Identitet", in Atkinson, D., Jackson, P., Sibley, D. and Washbourne, N. (Eds.), Cultural Geography: Critical Keyword Key Dictionary (in Croatian), Disput, Zagreb, pp. 135-141.

Massey, D. (1994), Space, place and gender, University of Minnesota Press, Minneapolis.

Massey, D.S., Arango, J., Hugo, G., Kouaouci, A., Pellegrino, A. and Taylor, J.E. (1993), "Theories of International Migration: A Review and Appraisal", Population and Development Review, Vol. 19, No. 3, pp. 431-466. https://doi.org/10.2307/2938462

McConnell, C.R. and Brue, S.L. (1992), Contemporary economy of work (in Croatian), Mate, Zagreb

Ministry of Tourism (2019), Turizam u brojkama (Tourism in numbers), viewed 10 May 2019, https://mint.gov.hr/UserDocsImages/AA_2018_c-dokumenti/190614_HTZ\%20TUB_2018_hrv. pdf

Navratil, F.J. and Doyle, J.J. (1977). "The socioeconomic determinants of migration and the level of aggregation", Southern Economic Journal, Vol. 43, No. 4, pp. 1547-1559. https://www.jstor.org/stable/1057119

Relph, E. (1976), Place and Placelessness, Pion, London.

Republic of Croatia (2012-2019), "Decision on determining the annual quota for the employment of foreigners for the calendar year", Official Gazette No. 25/2012, 144/2012, 151/2013, 151/2014, 39/2016, 118/2016, 74/2017, 71/2018, 116/2018, Zagreb.

Selwyn, T. (1996), "Introduction", in Selwyn, T. (Ed.), The Tourist Image: Myths and Myth Making in Tourism, Wiley, Chichester, pp. 1-32.

Soja, E.W. (1989), "Taking Los Angeles Apart: Towards a Postmodern Geography", in Soja E. (Ed.) Postmodern Geographies: The Reassertion of Space in Critical Social Theory, Verso, London, pp. 222-248.

Szivas, E. (1997), A study of labour mobility into tourism, PhD Thesis. University of Surrey, School of management studies for the service sector.

Szivas, E., Riley, M. and Airey, D. (2003), "Labour mobility into tourism: Attraction and Satisfaction", Annals of Tourism Research, Vol. 30, No. 1, pp. 64-76. https://doi.org/10.1016/S0160-7383(02)00036-1

Tuan, Y. (1977), Space and Place: the perspective of experience, University of Minnesota, Minneapolis.

Vaugeois, N. and Rollins, R. (2007), "Mobility into tourism: Refuge Employer?", Annals of Tourism Research, Vol. 34, No. 3, pp. 630-648. https://doi.org/10.1016/j.annals.2007.02.001 
ToSEE - Tourism in Southern and Eastern Europe, Vol. 5, pp. 275-289, 2019

D. Ferjanić Hodak, O. Kesar, I. Matečić: THE INFLUENCE OF FOREIGN LABOUR FORCE ON ...

Danijela Ferjanić Hodak, PhD, Assistant Professor

University of Zagreb, Faculty of Economics \& Business

Department of Tourism

Trg J. F. Kennedyja 6, 10000 Zagreb, Croatia

Phone: +385-1-2383-269

E-mail: dferjanic@efzg.hr

Oliver Kesar, PhD, Full Professor

University of Zagreb, Faculty of Economics \& Business

Department of Tourism

Trg J. F. Kennedyja 6, 10000 Zagreb, Croatia

Phone: +385-1-2383-459

E-mail: okesar@efzg.hr

Ingeborg Matečić, $\mathrm{PhD}$, Assistant Professor

University of Zagreb, Faculty of Economics \& Business

Department of Tourism

Trg J. F. Kennedyja 6, 10000 Zagreb, Croatia

Phone: +385-51-2383-269

E-mail: imatecic@efzg.hr 